\title{
Pengaruh Kemampuan Motorik di Sekolah dan Rumah Terhadap Kreativitas Anak Usia Dini
}

\author{
Aini Indriasih \\ Universitas Terbuka, Semarang, Indonesia \\ aini@ecampus.ut.ac.id

\section{Sumaji} \\ Universitas Muria Kudus, Kudus, Indonesia \\ sumaji@umk.ac.id
}

Abstract: The Influence of Motor Skills in Schools and Home on The Creativity of Early Children. The purpose of this study was to determine the effect of motor skills at home and school on the creativity of early childhood. This type of research is quantitative research. This research was conducted at Pertiwi Prambatan Lor Kindergarten, Kudus Regency. The research subjects were group A students, totaling 26 children. Test and observation data collection techniques. Prior to the data analysis, prerequisite tests were carried out, namely normality and homogeneity tests. The data analysis in this study was carried out using the F-test significance test which was used to determine the effect of each independent variable on the dependent variable. The results showed that (1) motoric at school (X1) and motoric at home (X2) had an effect on student creativity, (2) motoric at school (X1) had an effect on student creativity, and (3) motoric at home (X2) had an effect on student creativity. So the motor variable in students has a positive effect on students' creativity.

Keywords: Life skills, motor skills, early childhood

Abstrak: Tujuan penelitian ini adalah untuk mengetahui pengaruh ketrampilan motorik di rumah dan sekolah terhadap kreativitas anak usia dini. Jenis penelitian ini adalah penelitian kuantitatif. Penelitian ini dilakukan di TK Pertiwi Prambatan Lor 
Kabupaten Kudus. Subjek peneliti annya siswa kelompok A yang berjumlah 26 anak. Teknik pengumpulan data tes dan observasi. Sebelum dilakukan analis data terlebih dahulu dilakukan uji prasyarat yaitu uji normalitas dan homogenitas. Analis data dalam penelitian ini dilakukan dengan menggunakan pengujian signifikansi Uji-F yang digunakan untuk mengetahui pengaruh masingmasing variabel independen terhadap variabel dependen. Hasil penelitian menunjukkan bahwa (1) Motorik di Sekolah (X1) dan Motorik dirumah (X2) berpengaruh terhadap kreativitas siswa, (2) motorik di Sekolah (X1) berpenngaruh terhadap kreativitas siswa, dan (3) Motorik di rumah (X2) berpengaruh terhadap kreativitas siswa. Jadi variabel Motorik di siswa berpengaruh positif pada kreativitas siswa.

Kata kunci: Anak usia dini, kecakapan hidup, keterampilan motorik

\section{A. Pendahuluan}

Pendidikan pada jenjang PAUD diselenggarakan dengan tujuan untuk membentuk atau menjadikan anak-anak Indonesia optimal tumbuh kembangnya dan memiliki kesiapan untuk menempuh jenjan pendidikan selanjutnya, serta dapat mengarungi kehidupan dimasa mendatang (Aden, 2011:57). Pada rentang usia 0 sampai dengan 6 tahun, anak mengalami masa keemasan yang merupakan masa di mana anak mu lai peka dan sensitife dalam menerima rangsangan.

Dilihat dari aspek perkembangannya, perkembangan otak pada anak usia dini, menempati posisi yang sangat penting, bayi yang baru lahir perkembangannya telah mencapai otak 25\% dari orang dewasa. Untuk mencapai perkembangan otak yang sempurna, otak diproses hingga usia anak mencapai usia 8 tahun. Oleh karena itu sampai pada usia 8 tahun perkembangan otak anak memegang peranan yang sangat penting, hal ini karena perkembangan otak mengalami lompatan yang sangat besar dan berjalan demikian pesat. Sehingga, anak usia dini juga disebut "Golden Age", karena mengalami perkembangan yang luar biasa.

Lebih lanjut Hibana (2002: 6) menjelaskan bahwa anak usia dini dapat dijadikan sebagai cermin untuk melihat bagaimana keberhasilan anak dimasa mendatang. Anak yang mendapatkan 
layanan yang baik semenjak usia 0 hingga 8 tahun memiliki harapan besar untuk meraih keberhasilan di masa mendatang. Usia dini merupakan kesempatan emas bagi anak untuk belajar, sehingga disebut usia emas (golden age). Pada usia ini, anak memiliki kemampuan untuk belajar yang luar biasa. (Mursid, 2015: 121). Masa anak usia dini merupakan masa emas bagi pertumbuhan dan perkembangan pada anak, oleh karena itu penting sekali dalam mengarahkan dan membimbing anak dengan contoh dan karakter positif pada anak agar anak berkembang sesuai dengan tahap usianya, "Pendidikan anak usia dini sebagai pendidikan yang diselenggarakan sebelum jenjang pendidikan dasar, memiliki kelompok sasaran anak usia 0-6 tahun yang sering disebut sebagai masa emas perkembangan" (Latif, 2013:3).

Perkembangan motorik merupakan salah satu bagian yang harus ditumbuh dan kembangkan melalui proses pendidikan secara berkesinambungan (Goodway, Ozmun \& Gallahue, 2019). Perkembangan motorik merupakan bagian yang berhubungan dengan kemampuan gerak fisik pada anak usia dini (Stodden, 2008).

Masa anak usia dini atau masa prasekolah merupakan masa keemasan atau dikenal dengan golden age, merupakan masa yang biasanya ditandai oleh perubahan cepat dalam perkembangan fisik, kognitif, sosial dan emosional. Untuk itu agar masa ini dapat dilalui dengan baik oleh setiap anak maka perlu diupayakan pendidikan yang tepat bagi anak sejak usia dini. Di samping itu berbagai penelitian menyebutkan bahwa pada masa usia dini seluruh aspek perkembangan kecerdasan yaitu kecerdasan intelektual, kecerdasan emosi dan kecerdasan spiritual mengalami perkembangan yang sangat luar biasa (Garnerd dalam Morrison, 2012).

Seiring dengan berbagai perkembangannya, guru harus lebih kreatif dalam mengajar sehingga tidak membosankan siswa, sehingga dapat membantu memotivasi perkembangan yang sedang terjadi. Oleh karena itu, guru harus mencari media dan alat peraga pembelajaran yang relevan dan sesuai dengan perkembangan anak usia dini. Di samping itu, peran guru dalam menyampaikan pembelajaran pada anak usia dini harus memperhatikan tahap-tahap perkembangan dan masa peka setiap anak. Pembelajaran pada anak usia dini seharusnya 
ditujukkan pada pembentukan keterampilan hidup yang komprehensif dan bukan pada kecerdasan kognitif saja.

Peningkatan keterampilan hidup bagi anak usia dini dibutuhkan agar anak dapat memenuhi kebutuhan dasarnya sehari-hari seperti makan, minum, mandi sendiri, memakai baju, sandal, sepatu tanpa bantuan orang lain. Proses pembelajar dilakukan dengan tujuan memberikan konsep dasar yang memiliki kebermaknaan bagi anak melalui pengalaman nyata yang memungkinkan anak untuk menunjukkan aktivitas dan rasa ingin tahu secara optimal. Kemudian menempatkan posisi guru sebagai pendamping, pembimbing, dan fasilitator bagi anak. Proses pendidikan seperti ini dapat menghindari bentuk pembelajaran yang hanya berorientasi pada kehendak guru dan menempatkan anak secara pasif dan guru menjadi dominan. (Nurani, 2011)

Pada kenyataannya, pembelajaran berpusat pada anak untuk selama ini masih jauh dari yang diharapkan. Proses pembelajaran di banyak lembaga pendidikan masih berpusat pada guru (teacher centered) dan belum berpusat pada anak (student centered), sehingga cenderung tidak mengembangkan cara be rpikir kritis, kreatif dan inovatif. (Nurani , 2011). Lebih lanjut dikatakan bahwa kenyataan di lapangan guru yang lebih menginginkan anaknya duduk manis, diam, dan menjadi pendengar saja. Anak kreatif dan banyak bertanya justru dipandang sebagai anak yang nakal yang tidak disukai oleh guru dan selalu dianggap memusingkan. Keterampilan hidup atau kecakapan hidup (life skills) haruslah ditumbuh kembangkan sejak dini. Maddaleno dan Infante (2001:54), mengidentifikasi adanya tiga katagori life skills, yaitu keterampilan sosial dan interpesonal, keterampilan kognitif, dan keterampilan meniru emosi (emosional copying skills). Melalui berbagai keterampilan hidup yang dikuasainya, diharapkan anak akan mampu bertahan hidup dan bertanggung jawab terhadap dirinya sendiri. Catron dan Allen (1999:205) menyatakan bahwa pada dasarnya pembelajaran kecakapan hidup bertujuan agar anak mampu mengurus diri sendiri (self help) dan untuk kemudian mampu menolong orang lain (social skill) sebagai suatu bentuk kepedulian dan tanggung jawab sosialnya sebagai salah satu anggota keluarga dan masyarakat.

Aspek keterampilan hidup untuk kemandirian sesuai dengan karakteristik perkembangan anak usia dini antara lain 
adalah dapat mempergunakan serbet dan membersihkan sisa makanan, dapat menuangkan air dan minum sendiri, dapat makan sendiri, dapat memakai dan melepas pakaian sendiri, dapat memakai sepatu tanpa tali, dapat mencuci tangan sendiri, dapat ke kamar kecil dan membersihkan dirinya saat buang air, membuka dan menutup keran air, menyikat gigi dengan dibimbing, dan menyimpan mainan atau peralatannya sendiri pada tempatnya. Salah satu faktor utama yang mendukung terjadinya proses belajar mandiri dalam diri anak adalah interaksi anak dengan lingkungan. Dengan demikian anak menjadi terampil dan kreatif dalam mengerjakan tugas kemandiriannya untuk kebutuhan pribadinya. Penerapan pembelajaran berbasis kecakapan hidup ini dimungkinkan akan mengembangkan kecerdasan jamak dari anak. Hal ini dikarenakan anak berlatih aneka keterampilan dimana keterampilan-keterampilan yang dilatihkan akan mengembangkan setiap aspek kecerdasan jamak/majemuk.

\section{B. Pembahasan}

\section{Kajian Teori}

\section{a. Pembelajaran Kecakapan Hidup}

Saat ini, pembelajaran berpusat pada anak (student center learning) masih jauh dari harapan. Faktanya menunjukkan bahwa proses pembelajaran di berbagai lembaga pendidikan masih berpusat pada guru (teacher center learning) masih belum berpusat pada anak (student center learnig). Pembelajaran berpusat pada guru tidak dapat mengembangkan cara berpikir kritis, kreatif dan inovatif (Yuliani, 2011). Maddaleno dan Infante (2001:54), menjelaskan terdapat tiga karakteristik antara lain: (1) life skills, yaitu keterampilan sosial dan interpesonal, (2) keterampilan kognitif, dan (3) keterampilan meniru emosi (emosional copying skills). Melalui life skill yang dikuasainya, diharapkan peserta didik mampu bertahan hidup dan bertanggung jawab terhadap dirinya sendiri. Catron dan Allen (1999:205) mengungkapkan bahwa pada prinsipnya pembelajaran kecakapan hidup diharapkan agar anak mampu mengurus diri sendiri (self help) dan mampu menolong orang lain (social skill) sebagai wujud kepedulian dan tanggung jawab sebagai makhluk sosial dan sebagai anggota masyarakat. 
Aspek kecakapan hidup yang diajarkan di sekolah adalah kemandirian yang sesuai dengan karakteristik perkembangan dan pertumnuhan anak usia dini antara lain yaitu memakai baju dan makan sensiri, dapat memakai sepatu tanpa tali sendiri, dapat mencuci tangan sendiri, dapat buang air ke kamar kecil dan membersihkannya, membuka dan menutup keran air, menyikat gigi, dan menyimpan mainan atau peralatannya sendiri pada tempatnya.

Salah satu faktor utama yang dapat mendukung terjadinya proses belajar mandiri pada diri anak adalah interaksi anak dengan lingkungan sekitar. Oleh karena itu anak menjadi kreatif dan kritis dalam mengerjakan tugas secara mandiri untuk kebutuhan dirinya sendiri. Penerapan pembelajaran berbasis kecakapan hidup (life skill) ini memberikan peluang kepada dalam mengembangkan kecerdasan jamak daripada anak. Hal ini dikarenakan anak berlatih aneka keterampilan dimana keterampilan-keterampilan yang dilatihkan akan mengembangkan setiap aspek kecerdasan jamak/majemuk. Permasalhan yang diangkat pada peneitian ini Apakah pembelajaran berbasis kecakapan hidup berpengaruh terhadap peningkatan kemampuan motorik anak usia dini.

Peningkatan keterampilan hidup bagi anak usia dini dibutuhkan agar anak dapat memenuhi kebutuhan dasarnya sehari-hari seperti makan, minum, mandi sendiri, memakai baju, sandal, sepatu $t$ anpa bantuan orang lain. Proses pembelajar dilakukan dengan tujuan memberikan konsep dasar yang memiliki kebermaknaan bagi anak melalui pengalaman nyata yang memungkinkan anak untuk menunjukkan aktivitas dan rasa ingin tahu secara optimal. Kemudian menempatkan posisi guru sebagai pendamping, pembimbing, dan fasilitator bagi anak. Proses pendidikan seperti ini dapat menghindari bentuk pembelajaran yang hanya berorientasi pada kehendak guru dan menempatkan anak secara pasif dan guru menjadi dominan (Yuliani, 2011).

Kecakapan Hidup Anak Usia Dini Depdiknas (2003) mendefinisikan bahwa kecakapan hidup adalah kecakapan yang dimiliki oleh seseorang agar berani dan mau menghadapi segala permasalahan kehidupan dengan aktif dan proaktif sehingga dapat menyelesaikannya. Kecakapan hidup dapat dikategorikan menjadi dua kecakapan utama, yaitu generik dan spesifik. Pembelajaran kecakapan hidup pada pendidikan anak usia dini 
sebaiknya telah mulai dilakukan di rumah dan jauh sebelum anak tersebut masuk ke Kelompok Bermain atau Taman KanakKanak. Sejak anak berusia 18 bulan, anak sudah menunjukkan keinginannya untuk mandiri, walaupun masih sedikit tergantung pada orangtuanya. Anak pada usia itu sudah ingin makan sendiri, mandi sendiri, menuang air dan minum sendiri, serta masih banyak aktivitas lainnya. Oleh karena itu, sangatlah penting pendidikan kecakapan hidup dimasukkan dalam kurikulum pendidikan anak usia dini untuk memberi kesempatan pada anak meningkatkan kemampuan life skillnya. Biasanya pendidikan ini menyatu dalam berbagai aktivitas anak di sekolah. Pelajaran makan misalnya, yang di dalamnya terdapat pelajaran life skill, seperti berbagi, menunggu giliran, mau antri, membersihkan remah-remah bekas makanannya atau melap air yang tumpah. Pendidikan kecakapan hidup pada anak usia dini paling tidak harus berorientasi pada tiga hal, yaitu: (1) pengembangan keterampilan, (2) penekanan terhadap kompetensi psikososial, serta (3) partisipasi aktif anak (Widya, 2011).

Pengembangan keterampilan adalah gabungan antara pengetahuan dan keterampilan fakultatif (seperti menggambar, mencoret, mewarna) dengan keterampilan sosial emosional untuk mengaplikasikan keterampilan fakultatif tersebut dalam sebuah perilaku perilaku tertentu. Widya, (2011) menyebutkan bahwa kompetensi psikososial dalam kecakapan hidup mencakup lima hal. Pertama, empati (kesadaran diri). Empati merupakan kemampuan untuk merasakan sesuatu yang dirasakan oleh orang lain. Dengan demikian, anak mampu merasakan atau peka terhadap perasaan teman, orang tua, maupun guru yang ada di sekitarnya. Kemampuan ini harus didukung oleh kemampuan untuk diri sendiri, mengenal kekurangan dan kelebihan diri, sehingga dapat mengenal orang lain dari sudut pandang orang lain. Kedua, komunikasi hubungan interpersonal. Kemampuan berkomunikasi hendaknya dikembangkan sejak usia dini, karena pada masa tersebut merupakan proses pengembangan interaksi dengan orang lain. Untuk itu, pengembangannya harus dilakukan bersama-sama dengan kemampuan untuk melakukan hubungan interpersonal. Ketiga, pengambilan keputusan dalam pemecahan masalah (problem solving). Permasalahan yang pasti akan dihadapi oleh anak-anak di masa mendatang adalah 
banyaknya pilihan mengenai berbagai hal, mulai dari yang paling sederhana hingga yang paling kompleks. Maka dari itu, anak-anak perlu kita bekali dengan kemampuan untuk mengambil atau menentukan pilihan yang terbaik. Di samping itu, anak-anak juga akan menghadapi banyak permasalahan yang perlu dipecahkan, sehingga bekal kemampuan pemecahan masalah amatlah diperlukan. Keempat, berpikir kreatif dan kritis. Berpikir kreatif sangat diperlukan dalam menghadapi segala situasi dan kondisi, terutama pada saat menghadapi dan memecahkan masalah. Berpikir kreatif memberikan bekal kepada anak-anak untuk melihat segala sesuatu dari berbagai sudut pandang tanpa merasa takut salah. Ini memberikan bekal bagi anak-anak untuk tetap bertahan. Demikian pula dengan pola berpikir kritis. Kemampuan berpikir kritis memberikan bekal kepada anak-anak untuk dapat memilah yang benar dan salah serta yang relevan dan tidak. Kelima, mampu menanggulangi masalah-masalah emosional. Seringkali permasalahan bukan hanya berkaitan dengan logika, tetapi juga dengan emosi. Kematangan emosi anak-anak akan sangat membantu dalam menanggulangi stres, sehingga kualitas hidup anak tidak terganggu tetapi bahkan menjadi lebih baik. Selanjutnya, partisipasi aktif anak dikembangkan terutama untuk menumbuhkan ketegaran mental emosional yang ditunjukkan dengan rasa percaya diri dan sikap untuk menghargai diri sendiri. Dengan demikian, pendidikan kecakapan hidup tidak hanya mengembangkan kemampuan kognitif, tetapi juga mengembangkan sikap dan perilaku anak. Pendidikan kecakapan hidup dapat diberikan di keluarga ataupun lembaga pendidikan anak usia dini, misalnya di kelompok bermain, taman penitipan anak, taman-kanak-kanak, ataupun lembaga sejenis. Melalui pendidikan kecakapan hidup pada usia dini diharapkan kelak anak akan lebih siap dalam menghadapi permasalahan di masyarakat, sehingga tidak akan terbawa arus, negatif.

Seiring dengan berbagai perkembangannya, anak usia dini sebagai peserta didik menuntut guru untuk mengajar lebih kreatif dan tidak membosankan, sehingga dapat membantu memotivasi perkembangan yang sedang terjadi. Oleh karena itu, guru harus mencari media pembelajaran yang cocok dan sesuai dengan perkembangan anak usia dini. Di samping itu, peran guru dalam menyam paikan pembelajaran pada anak usia dini 
harus memperhatikan tahap-tahap perkembangan dan masa peka setiap anak. Pembelajaran pada anak usia dini seharusnya ditujukkan pada pembentukan keterampilan hidup, bukan pada kecerdasan kognitif saja.

\section{b. Kemampuan Motorik Anak Usia Dini}

Ketrampilan motorik berasal dari kata motor yang artinya "dasar mekanika yang mengakibatkan terjadinya suatu gerak". Gerak (movement) adalah merupakan aktivitas yang didasari oleh suatu proses motorik/gerak. Proses motorik melibatkan suatu sistem pola gerakan yang sudah terstruktur dan terkoordinasi dengan baik yang melibatkan (otak, saraf, otot, dan rangka) dengan proses mental yang sangat kompleks, yang disebut sebagai proses penciptaan gerak. Ketrampilan motorik merupakan salah satu perkembangan pada anak yang berkaitan dengan perkembangan fisik yang melibatkan kemampuan motorik kasar (otot besar) dan motorik halus (otot kecil). Menurut Elizabeth Hurlock (1978), "Perkembangan Motorik merupakan perkembangan pada aspek gerakan fisik melalui kegiatan pusat saraf, urat saraf, dan otot yang terkoordinasi." Berdasarkan pendapat tersebut, indikator dari keterampilan anak usia dini pada aspek jasmaniah antara lain (1) perubahan bentuk badan (2) perubahan otot (3) pertumbuhan tulang (4) penambahan kemampuan motorik kasar (5) perbedaan jenis kelamin dalam perkembangan motorik kasar (6) perubahan dalam ukuran badan (7) pengaruh hormon dalam perkembangan fisik (8) pertumbuhan fisik yang tidak sesuai.

Faktor-faktor yang mempengaruhi perkembangan motorik anak usia dini yang menyebabkan perbedaan individual antara anak yang satu dengan yang lain menurut Endang (2007) yaitu : (a) sifat dasar genetik atau faktor pembawaan (b) keaktifan janin dalam kandungan (c) kondisi prenatal yang menyenangkan, khususnya kondisi ibu dan gisi makanannya (d) proses kelahiran apabila ada kerusakan pada otak akan memperlambat perkembangan motoriknya (e) cacat fisik akan memperlambat perkembangan motorik anak (f) kondisi proses lahir berkaitan dengan kondisi lingkungan sekitar yang dapat menghambat atau mempercepat laju perkembangan motorik (g) ada tidaknya rangsangan, dorongan dan kesempatan untuk menggerakkan semua anggota tubuh. Milestone dalam Gronlund (2001) berpendapat bahwa, perkembangan motorik 
halus pada anak usia empat dan lima tahun antara lain : (1)untuk anak usia empat tahun antara lain (a) menyusun pluzze dengan potongan sedikit, meronce, bermain playdough dan lainnya (b) menuang air dan pasir ke dalam wadah kecil (c) membangun struktur balok yang kompleks (d) menggambar orang paling sedikit empat bagian (e) memakai baju tanpa bantuan orang lain. (2) ntuk anak usia lima tahun antara lain (a) menyusun pluzze dengan jumlah yang lebih banyak, menggunakan permainan berukuran kecil dengan mudah (b) menyusun struktur dengan balok tiga demensi (c) menggambar orang dengan pola geometri (d) menulis nama pertama nama dan menulis beberpa huruf secara kasar atau belum rapi tetapi terbaca orang dewasa (e) menggunakan alat-alat potong tanpa bantuan oranmg lain (f) memakai baju dengan mudah dn mengikat tali sepatu dengan sedikit bantuan orang dewasa. Pada pelaksanaan aktivitas motorik halus, anak biasanya melakukan gerakan yang dilakukan secara berulang-ulang (repetition). Untuk menumbuhkan kemampuan anak dibutuhkan sesuatu yang membantu anak selalu berfokus. Jika seorang anak mengalami hambatan dalam menggerakkan sendi terkecilnya, maka anak perlu dilatih dan dibiasakan untuk menggunakan sendi yang lebih besar. Motorik kasar berhubungan dengan kegiatan fisik/jasmani dengan mempergunakan otot-otot besar, seperti otot lengan, otot tungkai, otot bahu, otot punggung dan otot perut yang dipengaruhi oleh kematangan fisik anak. Motorik kasar dilakukan dalam bentuk berjalan, berjinjit, melompat, mcloncat, berlari dan berguling. Perbedaan jensi kelamin mempengarui motorik setiap individu ada yang cepat ada yang lambat. Tahap perkembangan motorik kasar pada anak berdasarkan usianya untuk anak usia 4-5 tahun antara lain: berjalan, berlari, berbelok dan melompat dengan baik, melompat, meniti, memanjat dan daya tahan fisik. Untuk anak usia 5-6 tahun seperti melompat dengan lincah dan cepat, gerakan koordinasi untuk berenang, naik sepeda, meniti, melompat, meloncat dan memanjat dengan baik (Grounlund,2001).

Perkembangan pada motorik anak berfokus pada perkembangan pengendalian gerakan fisik melalui kegiatan pusat syaraf, urat syaraf, dan otot yang terkoordinasi (Hurlock, 1978). Lebih lanjut Hurlock (1978) menjelaskan bahwa sebagian besar tugas perkembangan pada anak yang paling 
penting adalah pada usia TK dan pada tahun awal sekolah, terdiri atas perkembangan motorik yang didasarkan atas penggunaan kumpulan otot yang berbeda secara terkoordinasi. Corbin (1980) menjelaskan bahwa perkembangan motorik merupakan kebugaran pada jasmani yang merupakan gerak dasar yang dapat mengembangkan kemampuan fisik pada anak, khususnya berhubungan dengan kebugaran jasmani. Kemampuan gerakakan fisik pada anak dapat berkembang jika aspek-aspek yang merupakan gerak dasar pada anak dikembangkan sejak usia dini. Rangkaian yang dilakukan di Taman Kanak-kanak merupakan dasar yang harus dilakukan dengan cermat dan benar. Apabila gerak yang dilakukan kurang benar akan mengarah pada dasar pembentukan otomatisasi gerak yang salah. Guru dan orang tua harus memberikan perhatian terhadap aktivitas gerak anak di sekolah maupun di rumah. Aktivitas motorik kasar yang dilakukan anak dalam bentuk kegiatan fisik atau jasmani sesuai dengan karakteristik pertumbuhan dan perkembangannya. Untuk kelompok A, anak dapat melakukan aktivitas fisik secara terkoordinasi dalam rangka kelenturan, keseimbangan dan kelincahan. Untuk kelompok B, anak diharapkan mampu melakukan aktivitas fisik secar terkoordinasi dalam rangka kelenturan, keseimbangan, kelincahan dan melatih keberanian. Aktivitas fisik yang dirancang dapat dimodifikasi tetapi tidak boleh menyimpang dari kompetensi yang ingin dicapai yang disesuaikan dengan kurikulum. Keterampilan gerak setiap anak tidak sama , misalnya lokomotor berjalan, yang perlu diperhatikan adalah langkah kaki (footwork), gerak pinggul (hip action) dan gerak lengan dan tangan (arm action), gerakan berlari (running) dan lompat, lonce (Orbin,1980). Contoh aktivitas lompat jauh melalui tiga tahapan gerak yang dilakukan oleh anak.

Lebih lanjut Orbin (1980) menyatakan bahwa persyaratan alat bermain pada anak usia dini sebagai alat pembelajaran harus tepat, sesuai dan memiliki keserasian ukuran (proporsional) dengan ukuran tinggi, berat tubuhnya, bentuknya disesuaikan dengan ukuran standart. Alat bermain yang digunakan harus memiliki aspek edukatif artinya disesuaikan dengan kurikulum dan didaktik metodik disesuaikan dengan perkembangan anak. Tehnik alat bermain harus yang mudah dalam pemakaiannya, aman dan tahan lama. Alat bermain harus memiliki estetika artinya memiliki 
keserasian ukuran, warna yang menarik perhatian anak dan kerapihan selalu dijaga. Dengan ketiga aspek tersebut agar anak didik tertarik untuk menggunakan alat bermain yang ada, sehingga termotivasi proses belajar mengajar melalui bermain di TK. Fungsi alat bermain adalah mengembangkan kemampuan gerak (motorik) anak untuk pertumbuhan dan perkembangan serta kesehatannya. Fungsi tersebut adalah : (1) memperkenalkan hidup sehat sejak dini (2) mengembangkan kemampuan motorik kasar (3) meningkatkan kesegaran jasmani (4) memperkenalkan gerakan yang indah melalui melalui irama music (5) melatih keterampilan gerak dan berpikir anak (6) membentuk, membangun dan memperkuat tubuh anak (7) meningkatkan perkembngan emosional anak (8) meningkatkan perkembangan social anak (9) mananamkan nilai-nilai sportivitas. Melalui pembelajaran motorik akan berpengaruh terhadap beberapa aspek kehidupan para siswa seperti: (1) melalui pembelajaran motorik anak mendapat hiburan dan memperoleh kesenangan, (2) melalui pembelajaran motorik anak dapat beranjak dari kondisi lemah me-nuju kondisi independen, (3) melalui pembelajaran motorik anak dapat menyesuaikan diri dengan lingkungan, (4) melalui pembelajaran motorik akan menunjang keterampilan anak dalam berbagai hal, dan (5) melalui pembelajaran motorik akan mendorong anak bersikap mandiri, sehingga dapat menyelesaikan segala persoalan yang dihadapinya (Decaprio, 2013: Decaprio, R. 2013. Aplikasi Teori Pembelajaran Motorik di Sekolah. Yogyakarta: Diva Press

\section{Metode}

Jenis penelitian ini adalah penelitian kuantitatif. Penelitian ini dilakukan di TK Pertiwi Prambatan Lor Kabupaten Kudus. Pelaksanaan penelitian ini meliputi penyusunan skenario pembelajaran dan Rencana Pelaksanaan pembelajaran/RKH, Untuk mengetahui kondisi awal anak sebelum diberikan perlakuan, terlebih dahulu diadakan assesmen berupa tes perbuatan dilakukan secara acak dan diobservasi, pelaksanaan pembelajaran kecakapan hidup dengan bantuan media realia yang sudah dipersiapkan melalui berbagai permainan yang telah dirancang oleh peneliti dan guru. Pelaksanaan perlakuan dalam penelitian ini disesuaikan dengan kegiatan pembelajaran yang berlangsung di TK tersebut. Sebelum pembelajaran 
dilakukan observasi/studi awal terlebih dahulu. Hal ini akan dibandingkan dengan hasil observasi setelah diberikan perlakuan pembelajaran berbasis kecakapan hidup berbantuan media realia. Setiap pertemuan memerlukan waktu 150 menit dengan perincian 30 menit untuk kegiatan pembukaan, 60 menit untuk kegiatan inti, 30 menit untuk istirahat, 30 menit untuk kegiatan penutup. Subjek penelitiannya siswa kelompok A yang berjumlah 26 anak. Teknik pengumpulan data tes perbuatan dan observasi. Tes dilakukan untuk mengetahui sejauh mana keterpahaman anak terhadap aktivitas yang diujikan oleh peneliti. Adapun tes yang diberikan kepada anak merupakan tes perbuatan, bukan tes tertulis. Sedangkan observasi yaitu melakukan pengamatan langsung ke objek penelitian untuk melihat kegiatan atau aktivitas anak selama pembelajaran yang dilakukan. Sebelum dilakukan analis data terlebih dahulu dilakukan uji prasyarat yaitu uji normalitas dan homogenitas. Analis data dalam penelitian ini dilakukan pengujian signifikansi Uji-F digunakan untuk mengetahui pengaruh masing-masing variabel independen terhadap variabel dependen. Kriteria pengujian yang digunakan adalah sebagai berikut:

a. Jika nilai $F_{\text {hitung }}>F_{\text {tabel }}$ atau nilai sig $<0,5$, maka $\mathrm{H}_{\mathrm{a}}$ diterima $\left(\mathrm{H}_{0}\right.$ ditolak) berarti berpengaruh signifikan

b. Jika nilai $\mathrm{F}_{\text {hitung }}<\mathrm{F}_{\text {tabel }}$ nilai sig $>0,5$, maka $\mathrm{H}_{\mathrm{a}}$ ditolak $\left(\mathrm{H}_{0}\right.$ diterima) berarti tidak ada pengaruh.

\section{Hasil}

a. Gambaran Umum Responden

Data penelitian dalam penelitian ini diperoleh menggunakan daftar pertanyaan yang disi oleh orang tua dan guru dengan melihat kemampuan motorik kecakapan hidup dan kretaivitas anak-anak TK Pertiwi Prambatan Lor Kabupaten. Subjek dalam penelitian ini adaah siswa kelompok B yang berjumlah 26 anak. Karakteristik responden penelitian pada Tabel 1.1 merupakan profil dari 26 responden yang diperoleh dari hasil observasi. Profil responden menjelaskan mengenai jenis kelamin, jenjang pendidikan, pangkat dan golongan pegawai, lamanya responden bekerja sebagai pengawas, dan peran pengawas dalam proses pengawasan. 
Tabel 1.1 Profil Responden (N=26)

\begin{tabular}{lll}
\hline Keterangan & Jumlah Anak & $\begin{array}{l}\text { Prosentase } \\
(\%)\end{array}$ \\
\hline Jenis Kelamin Anak & 12 & 46.2 \\
L & 14 & 53.8 \\
P & & \\
Usia Anak & 21 & 80.8 \\
5 & 5 & 19.2 \\
6 & & \\
Kelompok TK & 26 & 100 \\
B & & \\
Jenis Kelamin Orang Tua & 26 & 100 \\
P & & \\
$\begin{array}{l}\text { Pendidikan Orang Tua } \\
\text { SLTA }\end{array}$ & 26 & 100 \\
$\begin{array}{l}\text { Pekerjaan Orang Tua } \\
\text { Swasta }\end{array}$ & & \\
Tidak bekerja & 14 & 53.8 \\
Wiraswasta & 9 & 34.6 \\
\hline
\end{tabular}

Berdasarkan gender dalam penelitian, dapat dilihat bahwa siswa TK Pertiwi Prambatan Lor Kabupaten Kudus adalah siswa berjenis kelamin laki-laki lebih banyak dibanding dengan siswa yang berjenis kelamin perempuan, ini dapat dilihat bahawa jumlah siswa yang berjenis kelamin laki-laki berjumlah 12 orang atau $53,8 \%$ sedangkan siswa yang berjenis kelamin perempuan sebanyak 14 orang atau 46,2\%. Berdasarkan Usia siswa terdapat 2 (dua) usia yang sekolah pada TK Pertiwi Prambatan Lor Kabupaten yaitu usia 5 (lima) tahun sebanyak 21 orang atau 80,8\%, jumlah siswa yang berusia 5 (lima) tahun lebih banyak dari pada siswa yang berusia 6 (enam) tahun yang berjumah 5 (lima) siswa atau 19,2\%. Profil siswa dalam penelitian dapat diketahui bahwa 26 (dua pulih enam) atau $100 \%$ siswa adalah duduk pada kelas B.

Berdasarkan orang tua yang mendampingi siswa adalah berjenis kelamin perempuan dan berpendidikan SLTA sejumlah 26 (dua puluh enam) orang atau 100\% dari jumlah responden. Terkait dengan pekerjaan orang tua jumlah yang paling banyak adalah orang tua bekerja swasta berjumlah 14 (empat belas) orang atau $53,8 \%$, Wiraswasta berjumlah 3 (tiga) orang atau 
11,5\% dan Orang tua yang tidak bekerja berjumlah 9 (Sembilan) orang atau $34,6 \%$.

\section{b. Pengaruh Motorik Di Sekolah dan Rumah Terhadap Kreativitas Siswa}

1. Deskripsi Variabel Penelitian

Kuesioner yang terkumpul dari responden yang diisi oleh guru dan orang tua, dilakukan tabulasi yang digunakan untuk melakukan analisis data. Data yang ditabulasi oleh peneliti adalah semua data atas tanggapan atau jawaban yang berasal dari responden yang bersumber dari pertanyaan-pertanyaan yang berasal dari kuesioner penelitian.

\section{Kreativitas}

Variabel pertama adalah kreativitas, penelitian ini diukur dengan menggunakan instrumen yang terdiri dari 15 pertanyaan pada kuesioner. Pertanyaan kuesioner dan jawaban responden untuk masing-masing item pada kuesioner yang diberikan untuk variabel kretivitas tampak pada Tabel. 1.2 berikut.

Tabel 1.2 Instrumen Pertanyaan Kreativitas Kaitannya dengan

Kecakapan Hidup

\begin{tabular}{lll}
\hline Indikator & No & Indikator Observasi \\
\hline Rasa ingin tahu di & K1 & Sering bertanya di dalam kelas \\
dalam kelas & K2 & $\begin{array}{l}\text { Memberi tanggapan atau gagasan sesuai } \\
\text { materi }\end{array}$ \\
& K3 & $\begin{array}{l}\text { Mengerjakan tugas dengan baik } \\
\text { Orisinalitas tinggi }\end{array}$ \\
& K4 & $\begin{array}{l}\text { Berani mempertahankan } \\
\text { pendapat/gagasan }\end{array}$ \\
& K5 & Menghasilkan karya yang istimewa \\
& K6 & Bekerja walau sedikit bimbingan guru \\
Bersifat Imajinatif & K7 & Menceritakan kegiatan yang dilakukan \\
& K8 & Mengeluarkan gagasan baru \\
Apresiasi Seni & K9 & Melakukan Tindakan \\
& K10 & Membuat berbagai bentuk dari kegiatan \\
& K11 & yang dilakukan \\
& Kerbahasa dengan baik \\
Berani mengambil & K13 & Beraniatif mengakui kesalahan \\
resiko & K14 & Berani menerima tugas \\
& K15 & Memecahkan masalah yang ada \\
\hline
\end{tabular}




\section{Motorik}

Variabel motorik pada penelitian ini merupakan nilai dari 2 (dua) variabel penelitian yatu variabel motorik kecakapan hidup di sekolah, motorik kecakapan hidup di rumah. nilai masing-masing variabel dapat dijelaskan sebagai berikut.

a) Motorik Kecakapan Hidup di Sekolah

Variabel motorik kecakapan hidup disekolah merupakan indikator dari motorik yang pertama, hasil analisis diskriptif dijelaskan bahwa dalam penelitian ini kecakapan hidup disekolah diukur dengan menggunakan instrumen yang terdiri dari 10 pertanyaan yang ada pada kuesioner yang dijawab oleh guru dengan melihat perkembangan siswa. Pertanyaan kuesioner dan jawaban responden untuk masing-masing item pada kuesioner yang diberikan untuk variabel motorik kecakapan hidup di sekolah tampak pada Tabel 1.3, Tabel 1.4 dan Tabel 1.5.

Tabel 1.3 Instrumen Pertanyaan Motorik Kecakapan Hidup di Sekolah

\begin{tabular}{ll} 
No. & Indikator Observasi \\
\hline M1 & Memakai baju sendiri \\
M2 & Memakai kaos kaki dan sepatu \\
M3 & Memakai dasi dan topi \\
M4 & Makan dan minum sendiri \\
M5 & Mencuci alat makan \\
M6 & Mandi dan gosok gigi sendiri \\
M7 & Menyapu, membersihkan meja kursi. \\
M8 & Mengambil dan mengembali kan mainannya sendiri \\
M9 & Menyiapkan buku dan alat tulisnya sendiri. \\
M10 & Membantu guru dan teman dalam kegiatan di sekolah. \\
\hline
\end{tabular}


Tabel 1.4 Respon Jawaban Responden pada Item Kuesioner Motorik Kecakapan Hidup di Sekolah (sebelum dilatih)

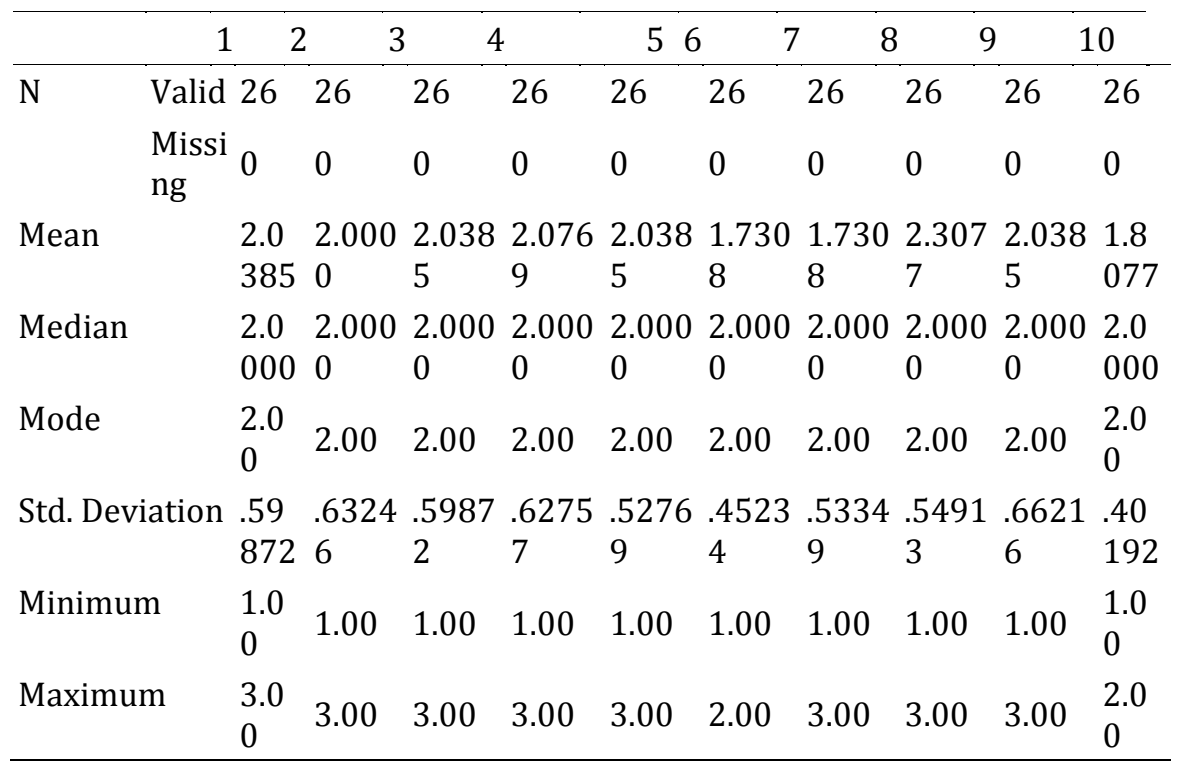

Tabel `1.5 Respon Jawaban Responden pada Item Kuesioner Motorik Kecakapan Hidup di Sekolah (sesudah dilatih)

\begin{tabular}{|c|c|c|c|c|c|c|c|c|c|c|}
\hline & 1 & 2 & 3 & 4 & 5 & 6 & 7 & 8 & 9 & 10 \\
\hline Valid & 26 & 26 & 26 & 26 & 26 & 26 & 26 & 26 & 26 & 26 \\
\hline Missing & 0 & 0 & 0 & 0 & 0 & 0 & 0 & 0 & 0 & 0 \\
\hline Mean & 2.7692 & 3.0769 & 2.9615 & $\begin{array}{l}3.153 \\
8\end{array}$ & $\begin{array}{l}3.269 \\
2\end{array}$ & $\begin{array}{l}2.730 \\
8\end{array}$ & 2.6538 & 3.3462 & 2.9615 & 2.8077 \\
\hline Median & 3.0000 & 3.0000 & 3.0000 & $\begin{array}{l}3.000 \\
0\end{array}$ & $\begin{array}{l}3.000 \\
0\end{array}$ & $\begin{array}{l}3.000 \\
0\end{array}$ & 3.0000 & 3.0000 & 3.0000 & 3.0000 \\
\hline Mode & 3.00 & 3.00 & 3.00 & 3.00 & 3.00 & 3.00 & 3.00 & 3.00 & 3.00 & 3.00 \\
\hline Std. Deviation & .65163 & .79614 & .77360 & $\begin{array}{l}.6126 \\
9\end{array}$ & $\begin{array}{l}.6038 \\
3\end{array}$ & $\begin{array}{l}.5334 \\
9\end{array}$ & .56159 & .56159 & .72004 & .56704 \\
\hline Minimum & 2.00 & 2.00 & 2.00 & 2.00 & 2.00 & 2.00 & 2.00 & 2.00 & 2.00 & 2.00 \\
\hline Maximum & 4.00 & 4.00 & 4.00 & 4.00 & 4.00 & 4.00 & 4.00 & 4.00 & 4.00 & 4.00 \\
\hline
\end{tabular}

Pada Tabel 1.5 dan Tabel 1.6 di atas dapat dijelaskan bahwa jumlah item pertanyaan dalam kuesioner variabel kreativitas berjumlah 10 pertanyaan. Tabel 1.5 dijelaskan dari indikator kecakapan hidup disekolah sebelum dilakukan pelatihan dan observasi, dari jumlah pertanyaan tersebut dapat dilihat rata- 
rata nilai yang paling tinggi adalah pertanyaan kuesioner nomor 8 dengan nilai rata-rata 2.3077. Dapat disimpulkan bahwa anakanak sudah berkebang mengambil dan mengembalikan mainannya sendiri meskipun masih ada bimbingan guru

Setalah ada obeservasi dan pelatihan dapat dilihat pada Tabel 1.5 dijelaskan dari indikator kecakapan hidup disekolah sesudah dilakukan pelatihan dan observasi, dari jumlah pertanyaan tersebut dapat dilihat rata-rata nilai yang paling tinggi adalah pertanyaan kuesioner nomor 8 dengan nilai ratarata 3.3462 ini dapat disimpulkan bahawa anak-anak sudah mulai berkembang sesuai yang diharapkan dalam mengambil dan mengembalikan mainannya sendiri. Dari data Tabel 1.5 dan Tabel 1.6 dapat disimpulkan secara keseluruhan dari hasil kuesioner terdapat perubahan yang sesuai harapan dari kreativitas anak-anak, ini dapat dilihat nilai rata-rat a dari kuesioner pra observasi dan post observasi mengalami perubahan dan kenaikan rata-rata. Nilai Standar deviasi untuk variabel Motorik kecakapan hidup di sekolah pada semua pertanyaan lebih kecil dari mean, ini dapat disimpulkan bahawa variansi data relatif lebih kecil.

b) Motorik Kecakapan Hidup di Rumah

Variabel motorik kecakapan hidup dirumah merupakan indikator dari motorik yang pertama, hasil analisis diskriptif dijelaskan bahwa dalam penelitian ini kecakapan hidup dirumah diukur dengan menggunakan instrumen yang terdiri dari 10 pertanyaan yang ada pada kuesioner yang dijawab oleh orang tua dengan melihat perkembangan anak. Hasil observasi yang diisi oleh orang tua dengan melihat perkembangan anak dapat diliat pada Tabel 1.6 dan Tabel 1.7.

Berdasarkan Tabel 1.6 dan Tabel 1.7 di atas dapat dijelaskan bahwa jumlah item pertanyaan dalam kuesioner variabel kreativitas berjumlah 10 pertanyaan. Tabel 1.6 dijelaskan dari indikator kecakapan hidup dirumah sebelum dilakukan pelatihan dan observasi, dari jumlah pertanyaan tersebut dapat dilihat rata-rata nilai yang paling tinggi adalah pertanyaan kuesioner nomor 2 dengan nilai rata-rata 2.7692 . Dapat disimpulkan bahwa anak-anak sudah berkebang memakai kaos kaki dan sepatu sendiri meskipun masih ada bimbingan orangtua 
Setalah ada obeservasi dan pelatihan dapat dilihat pada Tabel 1.7 dijelaskan dari indikator kecakapan hidup dirumah sesudah dilakukan pelatihan dan observasi, dari jumlah pertanyaan tersebut dapat dilihat rata-rata nilai yang paling tinggi adalah pertanyaan kuesioner nomor 2 dengan nilai ratarata 3.0769 ini dapat disimpulkan bahawa anak-anak sudah mulai berkembang sesuai yang diharapkan dalam memakai kaos kaki dan sepatu sendiri. Dari data Tabel 1.6 dan Tabel 1.7 dapat disimpulkan secara keseluruhan dari hasil kuesioner terdapat perubahan yang sesuai harapan dari kreativitas anakanak, ini dapat dilihat nilai rata-rat adari kuesioner praobservasi dan posobservasi mengalami perubahan dan kenaikan rata-rata. Nilai Standar deviasi untuk variabel Motorik kecakapan hidup di rumah pada semua pertanyaan lebih kecil dari mean, ini dapat disimpulkan bahawa variansi data relatif lebih kecil.

Tabel 1.6 Respon Jawaban Responden pada Item Kuesioner Motorik Kecakapan Hidup di Rumah (sebelum dilatih)

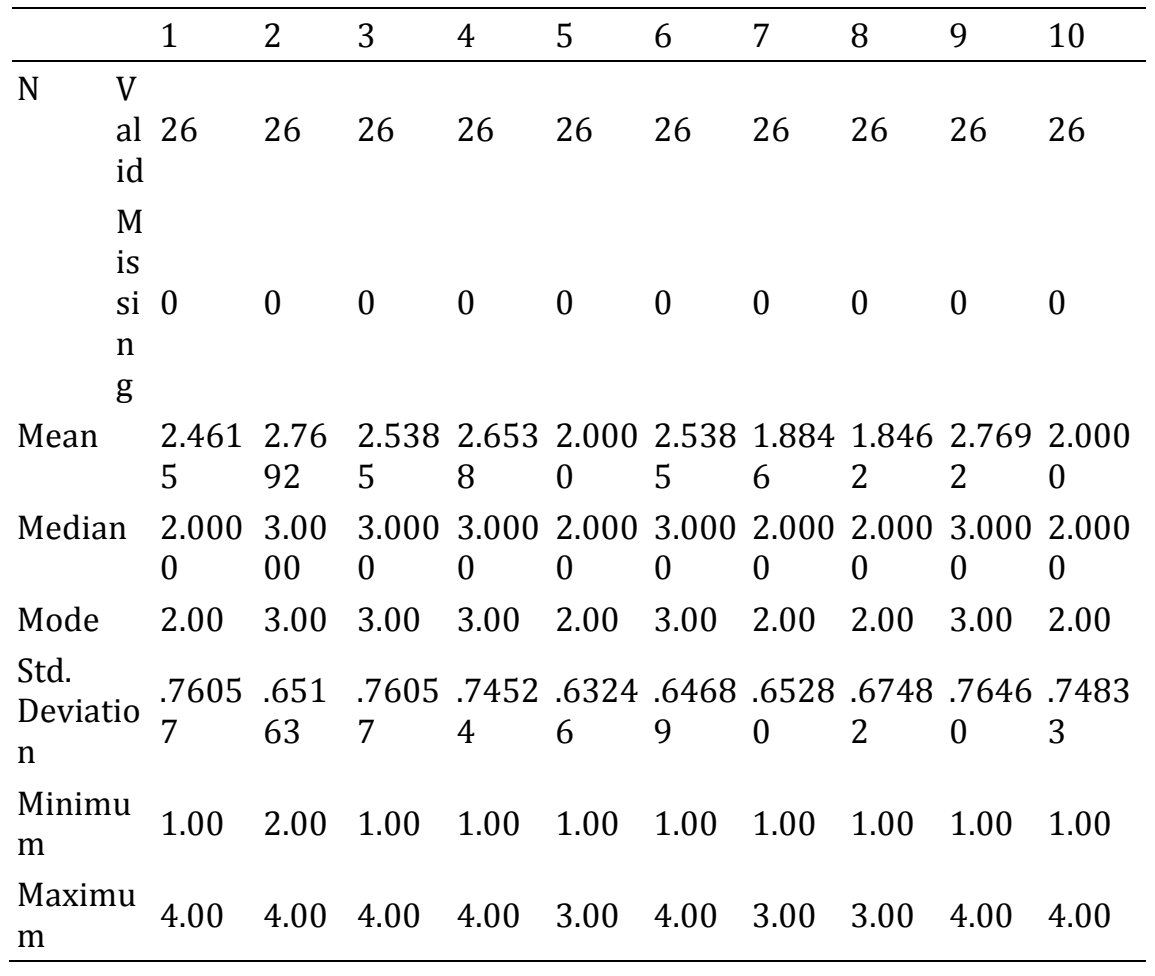


194 | Aini Indriasih dan Sumaji

Tabel 1.7 Respon Jawaban Responden pada Item Kuesioner Motorik Kecakapan Hidup di Rumah (seusdah dilatih)

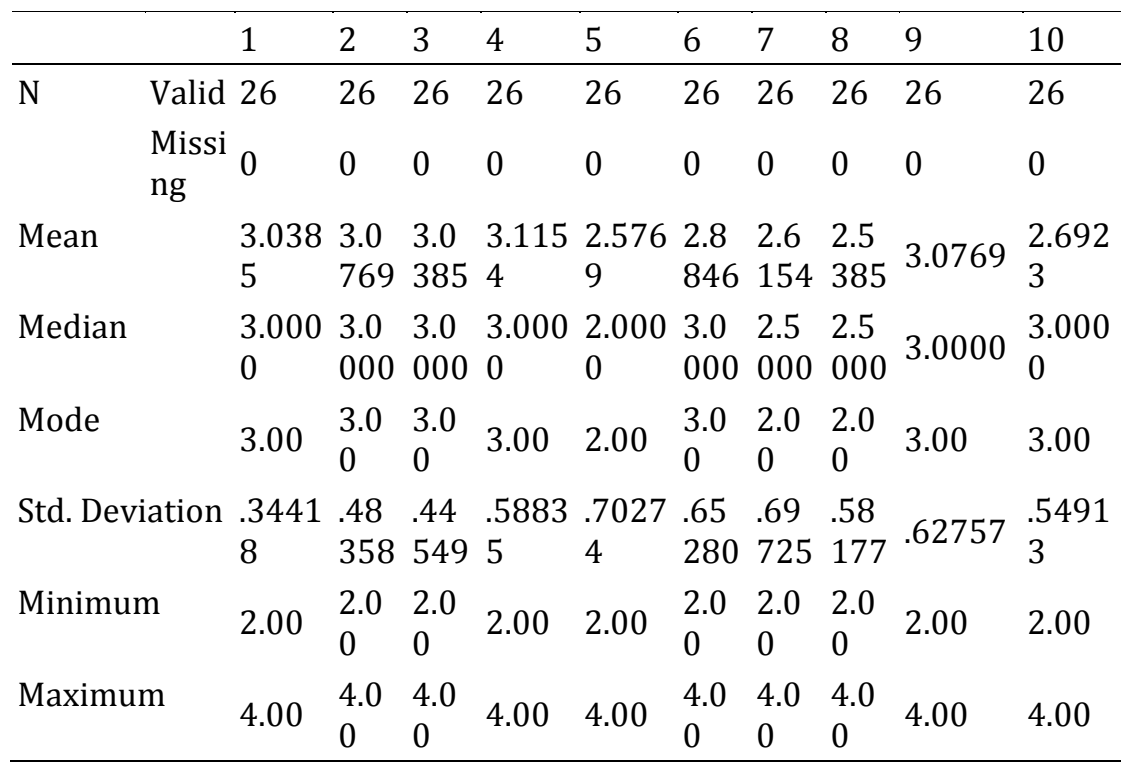

c. Uji Prasyarat

1) Uji Normalitas

Uji normalitas untuk mengetahui apakah data keadaan awal sampel berdistribusi normal atau tidak. Hipotesis yang diuji pada kelas tersebut adalah sebagai berikut.

$\mathrm{H}_{0}$ : rata-rata populasi adalah normal

$\mathrm{H}_{\mathrm{a}}$ : rata-rata populasi adalah tidak normal

Berdasarkan Tabel 1.8 dapat disimpulkan bahwa nilai signifikasinya (Sig.) > 0,05 maka distribusinya normal.

\section{2) Uji Simultan (Uji F)}

Model regeresi dalam penelitian ini adalah untuk menguji pengaruh variabel independen Motorik siswa di sekolah (X1), Motorik siswa di rumah (X2) terhadap variabel kretifitas (Y). Hasil pengaruh variabel independen Motorik siswa di sekolah (X1), Motorik siswa di rumah (X2) terhadap variabel kretifitas (Y) dengan uji simultan ANOVA atau $\mathrm{F}$ test seperti yang ditampilkan pada tabel 1.9 di bawah ini 
Tabel.1.8 Output SPSS

\begin{tabular}{llll}
\hline & & \multicolumn{2}{l}{ Kreativitas Motorik_sekolah } \\
\hline $\mathrm{N}$ & & 26 & 26 \\
Normal Parameters $^{\mathrm{a}}$ & Mean & 42.4231 & 29.7308 \\
& Std. Deviation & 5.96773 & 4.17188 \\
Most Extreme & Absolute & .192 & .161 \\
Differences & Positive & .113 & .084 \\
& Negative & -.192 & -.161 \\
Kolmogorov-Smirnov Z & & .981 & .822 \\
Asymp. Sig. (2-tailed) & & .291 & .509 \\
\hline
\end{tabular}

Tabel 1.9 Hasil Uji Simultan (UJI F)

\begin{tabular}{|c|c|c|c|c|c|c|}
\hline Model & & $\begin{array}{l}\text { Sum of } \\
\text { Squares }\end{array}$ & Df & Mean Square & $\mathrm{F}$ & Sig. \\
\hline \multirow[t]{4}{*}{1} & Regressio & 413143 & 2 & 206.572 & \multirow{4}{*}{$\begin{array}{l}29.52 \\
9\end{array}$} & .00 \\
\hline & & & & & & $0^{\mathrm{a}}$ \\
\hline & Residual & 160.895 & 23 & 6.995 & & \\
\hline & Total & 574.038 & 25 & & & \\
\hline
\end{tabular}

a. Predictors: (Constant), Motorik_rumah, Motorik_sekolah

b. Dependent Variable: Kreativitas

Berdasarkan Tabel 1.9 di atas, nilai $\mathrm{F}_{\text {hitung dibandingkan }}$ dengan $F_{\text {tabel }}$ dimana jika $F_{\text {hitung }}>F_{\text {tabel }}$ maka secara simultan variabel-variabel independen berpengaruh signifikan terhadap variabel dependen. Pada taraf $\alpha=0,05$ dengan derajat kebebasan pembilang/df1 (k) $=2$ (jumlah variabel kreativitas) dan derajat kebebasan penyebut/df2 $(n-k-1)=23$, diperoleh nilai $F_{\text {tabel }} 3,42$. Dengan demikian, nilai $F_{\text {hitung }} 29,529$ lebih besar dari nilai $F_{\text {tabel }}(3,42)$. Berdasarkan hasil perhitungan tersebut dapat diinterpretasikan bahwa variabel Motorik di Sekolah (X1), Motorik dirumah (X2) secara bersama-sama mempengaruhi variabel kreativitas siswa. Sejalan dengan hasil penelitian Wibowo (2020) antusias belajar anak dirumah meningkatkan kreativitas seni warna dengan menggunakan cat air. 
3) Uji Parsial (Uji t)

Hasil uji statistik t (uji hipotesis) menunjukkan besar pengar uh variabel independen secara individual dalam menerangkan variasi variabel independen. Untuk hasil pengujian secara parsial masing-masing variabel independen terhadap variabel dependen dapat dilihat pada Tabel. 1.10 dapat dijabarkan sebagai berikut:

1. Pengaruh Motorik di Sekolah terhadap kreativitas siswa.

Pengujian hipotesis pertama (H1) memiliki nilai $\mathrm{X} 1=0,850$ dengan tingkat signifikansi sebesar $0,000 \quad($ sig<0,05), sehingga H1 diterima. Jadi variabel Motorik di Sekolah berpengaruh positif pada kreativitas siswa.

2. Pengaruh Motorik di rumah terhadap kreativitas siswa.

Pengujian hipotesis pertama (H1) memiliki nilai $\mathrm{X} 2=0,110$ dengan tingkat signifikansi sebesar $0,000 \quad($ sig<0,05), sehingga $\mathrm{H} 1$ diterima. Jadi variabel Motorik di siswa berpengaruh positif pada kreativitas siswa.

Hasil pengujian terhadap uji Parsial (Uji t) dapat dilihat pada Tabel 1.10 berikut.

Tabel 1.10 Hasil Uji Parsial

\begin{tabular}{|c|c|c|c|c|c|}
\hline \multirow[t]{2}{*}{ Model } & \multicolumn{2}{|c|}{$\begin{array}{l}\text { Unstandardized } \\
\text { Coefficients }\end{array}$} & \multirow{2}{*}{\multicolumn{2}{|c|}{$\begin{array}{l}\text { Standardiz } \\
\text { ed } \\
\text { Coefficient } \mathrm{t} \\
\mathrm{s} \\
\text { Beta }\end{array}$}} & \multirow[t]{2}{*}{ Sig. } \\
\hline & B & Std. Error & & & \\
\hline 1 (Constant) & 6.774 & 3.579 & & 1.893 & .071 \\
\hline Motorik_sekolah & .850 & .122 & .815 & 6.943 & .000 \\
\hline Motorik_rumah & .110 & .151 & .086 & .730 & .473 \\
\hline
\end{tabular}

Dependent Variable: Kreativitas 


\section{Simpulan}

Berdasarkan hasil penelitian dapat disimpulkan bahwa (1) Motorik di sekolah (X1), Motorik dirumah (X2) berpengaruh terhadap kreativitas siswa, (2) Motorik di sekolah berpengaruh terhadap kreativitas siswa dan (3) Motorik di rumah berpengaruh terhadap kreativitas siswa.

\section{Referensi}

Depdiknas (2003) Model Pengembangan Motorik Anak Prasekolah: Jakarta Dirjen Olahraga Depdiknas Direktorat Olahraga Masyarakat.

Depdiknas (2003) PAKEM di Taman Kanak-kanak. Jakarta, Dirjen Mendikdasmen, Direktorat Pendidikan Taman Kanak-kanak dan Sekolah Dasar.

Depdiknas. (2003). Pedoman Penyelenggaraan Program Kecakapan Hidup (life skill) Pendidikan Luar Sekolah. Jakarta.

Depdiknas. (2008). Pengembangan Kemampuan Motorik Halus di Taman Kanak-kanak, Jakarta: Departemen Pendidikan Nasional

Depdiknas (2008) Pengembangan Kemampuan Motorik Kasar di Taman Kanak-kanak, Jakarta: Departemen Pendidikan Nasional.

Decaprio, R. 2013. Aplikasi Teori Pembelajaran Motorik di Sekolah. Yogyakarta: Diva Press

Endang Rini Sukamti. 2007. Pelatihan Senam Artistik Dasar Untuk Guru. Jakarta: PT Indeks

Goodway, JD., Ozmun, JC., \& Gallahue, DL. (2019).

Understanding Motor Development: Infant, Children, Adolescents, Adults. Eights Edition

Gronlund, N.E. \& Linn, R.L. (2001). Measurement and evaluation inteaching. NewYork: Macmillan Publishing.

Hibana, S Rahman. (2002). Konsep Dasar Pendidikan Anak Usia Dini. Yogyakarta: PGTKI Pres.

Hurloch, Elizabet (2010). Perkembangan anak, jilid 2; alih bahasa Meitasari Tjandrasa. Jakarta: Erlangga

Latif, Mukhtar, dkk., Orientasi Baru Pendidikan Anak Usia Dini,(Jakarta: Kencana Prenada Media Group, 2013). Maddaleno, Matilde dan Francisca Infante. (2004) Life Skills Approach toChild and Adolescent Healthy. USA: Pan American Health Organization. 
Mursid, Belajar dan Pembelajaran PAUD,(Bandung: PT. Remaja Rosdakarya, 2015).

Nurani Yuliani (2011) Konsep Dasar Pendidikan Anak Usia Dini. Jakarta: PT Indeks

Rachmawati, Y dan Kurniati, E (2012). Strategi Pengembangan Kreativitas Pada Anak Usia Taman Kanak-kanak. Jakarta: Kencana Prenada Media.

Stodden, DF., et.al. (2009). A Developmental Perspec-tive on the Role of Motor Skill Competence in Physical Activity: An Emergent Relationship.

Sujiono, Yuliani Nuraini, dan Bambang Sujiono. 2010. Bermain Kreatif Berbasis Kecerdasan Jamak. Jakarta: Indeks.

Sugiyono. 2010. Statistika Untuk Penelitian. Bandung: Alfabeta. Wibowo. D.V dan Suyadi (2020). Kegiatan

KreativitasSeniWarna Anak Usia Dini Melalui Permainan Cat Air diMasa Pandemi. Jurnal Pendidikan Anak Usia Dini. 4(1). 75-87 